\title{
Effect of long-term feeding with a plant protein mixture based diet on growth and body/fillet quality traits of large rainbow trout (Oncorhynchus mykiss)
}

\author{
Matilde de Francesco ${ }^{a}$, Giuliana Parisi ${ }^{\mathrm{a}}$, Françoise Médale ${ }^{\mathrm{b}}$, Paola Lupi $^{\mathrm{a}}$, \\ Sadasivam J. Kaushik ${ }^{\mathrm{b}}$ and Bianca M. Poli ${ }^{\mathrm{a},{ }^{*}}$
}

a : Dipartimento di Scienze Zootecniche, Università degli Studi di Firenze, Via delle Cascine 5, 50144-, Florence, Italy

b : Fish Nutrition Laboratory, Unité mixte INRA-IFREMER, Lab. de Nutrition des Poissons, Station

d'Hydrobiologie, BP 3, 64310 Saint Pée-sur-Nivelle, France

*: Corresponding author : Tel.: +39-55-3288405; fax: +39-55-321216

\section{Abstract:}

Two diets based on fish meal (FM) or on a mixture of plant protein sources supplemented with free amino acids (PP) were fed to rainbow trout having a mean initial body weight of $162.5 \mathrm{~g}$ reared at $17 \pm 1^{\circ} \mathrm{C}$ for 24 weeks to evaluate the effect of plant protein sources on fish growth, morphological and body quality traits. At the end of the growth study, samples were withdrawn for chemical analyses as well as measurements of different parameters of quality.

Compared to the FM group, the trout fed diet PP had lower growth rates (mean final body weight 663 vs. $800 \mathrm{~g}$ ), feed efficiency (0.95 vs. 1.07) and protein efficiency ratio (1.96 vs. 2.13). Trout fed diet PP were also characterised by a lower dressed weight (89.45\% vs. $91.07 \%)$, hepato-somatic index $(0.92 \%$ vs. $1.01 \%)$ and fillet lipid content (5.50\% vs. $6.98 \%)$, but had a higher mesenteric fat $(5.65 \%$ vs. $4.08 \%)$, viscero-somatic index (10.55\% vs. $8.93 \%)$ and fillet crude protein content $(20.53 \%$ vs. $19.93 \%)$. The muscle fatty acid composition reflected that of the diet with a higher level of polyunsaturated (n-6) fatty acids in trout fed diet PP and a higher content in polyunsaturated n-3 fatty acids and $n-3 / n-6$ ratio in trout fed diet FM. Sensory analysis was carried out at 5 days post-mortem on microwave-cooked dorsal portions of fillets stored at $1{ }^{\circ} \mathrm{C}$ with ice covering. The results of the triangular test showed differences between groups $(P<0.01)$ in organoleptic characteristics as well as in visual colour. Descriptive tests pointed out that fillets of trout fed diet PP exhibited higher hardness, less sweetness and less odour intensity than trout fed diet FM.

In summary, data show that long-term feeding a diet in which fish meal was totally replaced by a mixture of plant protein sources significantly affects growth and quality criteria such as morphometric traits, fat deposits, fillet chemical composition and organoleptic characteristics of large commercial size rainbow trout. 
1 Effect of long-term feeding with a plant protein mixture based diet on growth and body/fillet quality traits of large rainbow trout (Oncorhynchus mykiss)

Matilde de Francesco ${ }^{1}$, Giuliana Parisi ${ }^{1}$, Françoise Médale $^{2}$, Paola Lupi ${ }^{1}$, Sadasivam J. Kaushik ${ }^{2}$, Bianca M. Poli ${ }^{1}$

${ }^{1}$ Dipartimento di Scienze Zootecniche, Università degli Studi di Firenze, Via delle Cascine 5, 50144-Florence, Italy

${ }^{2}$ Fish Nutrition Laboratory, UMR NuAGe, INRA-IFREMER-U BordeauxI, Fish Nutrition Lab Station d'Hydrobiologie, BP 3, 64310 Saint Pée-sur-Nivelle, France

Corresponding author. Bianca Maria Poli: biancamaria.poli@unifi.it

\section{Abstract}

Two diets, either based on fish meal (FM) or on a mixture of plant protein sources supplemented with free amino acids (PP) were fed to rainbow trout having a mean initial body weight of $162.5 \mathrm{~g}$ reared at $17 \pm 1{ }^{\circ} \mathrm{C}$ for over $24 \mathrm{wks}$, in order to evaluate the effect of plant protein sources on fish growth, morphological and body quality traits. At the end of the growth study, samples were withdrawn for chemical analyses as well as measurements of different parameters of quality.

Compared to the FM group, the trout fed diet PP had lower growth rates (mean final body weight 663 vs $800 \mathrm{~g}$ ), feed efficiency (0.95 vs 1.07$)$ and protein efficiency ratio (1.96 vs 2.13). Trout fed diet PP were also characterised by a lower dressed weight ( 89.45 vs $91.07 \%$ ), hepato-somatic index ( 0.92 vs $1.01 \%$ ) and fillet lipid content (5.50 vs $6.98 \%)$, but had a higher mesenteric fat (5.65 vs $4.08 \%)$, viscero-somatic index (10.55 vs $8.93 \%)$ and fillet crude protein content (20.53 vs 19.93 $\%)$. The muscle fatty acid composition reflected that of the diet with a higher level of polyunsaturated (n-6) fatty acids in trout fed diet PP and a higher content in polyunsaturated n-3 fatty acids and n-3/n-6 ratio in trout fed diet FM. Sensory analysis was carried out at 5 days postmortem on microwave-cooked dorsal portions of fillets stored at $1{ }^{\circ} \mathrm{C}$ with ice covering. The results of the triangular test showed differences between groups $(\mathrm{P}<0.01)$ in organoleptic characteristics as 
1 well as in visual colour. Descriptive tests pointed out that fillets of trout fed diet PP exhibited higher

2 hardness, less sweetness and less odour intensity than trout fed diet FM.

3 In summary, data show that long-term feeding with a diet in which fish meal was totally replaced by

4 a mixture of plant protein sources significantly affects growth and quality criteria such as 5 morphometric traits, fat deposits, fillet chemical composition and organoleptic characteristics of $6 \quad$ large commercial size rainbow trout.

7

8 Keywords: Oncorhynchus mykiss; Plant protein; Body traits; Flesh; Chemical composition;

9 Quality; Sensory evaluation 


\section{Introduction}

It is generally well recognised that over reliance on marine fishery resources is not a sustainable practice for aquaculture development (Hardy, 1999; Naylor et al., 2000; New and Wijkstroem, 2002). Substitution of fish meal by alternate protein sources has been the object of study since more than three decades (Fowler, 1980; Dorsa et al., 1982; Tacon et al., 1985; Smith et al., 1988), possibly reducing production costs but definitely having a beneficial impact on environmental loads, locally with regard to phosphorus discharge (Watanabe and Pongmaneerat, 1993; Ballestrazzi et al., 1994; Hardy, 1995; Burel et al., 1998; Riche and Brown, 1999; Barrias and Oliva-Teles, 2000) and globally over the preservation of wild fishery resources. In spite of the lower protein content, the deficiency in some indispensable amino acids (IAA) and the presence of anti-nutritional factors (ANFs) frequently found in most plant protein sources (Kaushik, 1990; Francis et al., 2001), many studies have demonstrated the possibility to incorporate such ingredients in feeds for salmonids (Gomes et al., 1993, 1995; Oliva-Teles et al., 1994; Hardy, 1996; Forster et al., 1999; Refstie et al., 2000; Burel et al., 2000; Vielma et al., 2000). Generally it has been observed that a partial substitution of fish meal by plant protein sources is well supported by fish, so currently more than $30 \%$ is already replaced in most commercial fish feeds (Teskeredzic at al., 1995; Forster et al., 1999; Burel et al., 2000; Vielma et al., 2000). Under conditions of partial replacement of fish meal, reasonably good growth performance has been observed with minor effects on metabolism (Gomes and Kaushik, 1990; Kaushik and Mambrini, 1994; Sanz et al., 1994; Carter and Hauler, 1995; Gomes et al., 1995; Robaina et al., 1995; Teskeredzic at al., 1995; Kissil et al., 2000; Refstie et al., 1997; Médale et al., 1998; Refstie et al., 2000). Fish meal free diets have also been used with success in some studies with rainbow trout (Kaushik et al., 1995; Watanabe et al., 1998).

The consequences of fish meal substitution on flesh quality traits have been investigated to some extent. Smith et al. (1988) working with different strains of rainbow trout fed either fish meal-based or plant protein-based diets did not find any differences in organoleptic quality or flesh acceptability 
1 associated with either strain or diet. Kaushik et al. (1995) did not find any major effects of total

substitution of fish meal by a soy protein concentrate. Even in marine fish, Aoki et al. (1996) did not find any difference in flesh quality between adult red sea bream fed with or without fish meal as the dietary protein source. Other studies (Lopez-Bote et al., 2001) suggest that peroxidative characteristics of fish muscle are susceptible to be affected by dietary protein sources. In most of the above-mentioned studies, the duration of growth trials were relatively short. The aim of this work was to study the long term effect of the total replacement of fish meal by a mixture of plant protein sources supplemented with free amino acids to suit the IAA composition of trout muscle on growth of rainbow trout and on several quality attributes.

\section{Materials and methods}

\subsection{Diets}

Two isoproteic $(50 \%$ crude protein, $\mathrm{CP})$ and isoenergetic $(23 \mathrm{~kJ} / \mathrm{g}$ dry matter, DM) diets, containing either fish meal as the major protein source (diet FM), or a mixture of plant protein sources (corn gluten meal, wheat gluten, extruded peas, rapeseed meal) adequately supplemented with free amino acids (diet PP) were used (Table 1). Both diets were formulated to meet the nutritional requirements of rainbow trout $(\mathrm{NRC}, 1993)$ and also contained synthetic astaxanthin as a pigment source. All dry ingredients were mixed and pelleted dry (4 mm diameter) using a SimonHeese (Holland) pelleting machine. Dietary amino acid and fatty acid profiles are provided in tables 2 and 3.

\subsection{Growth trials}

Triploid rainbow trout (ㅁcorhynchus mikyss) of the same lot (initial average body weight $162.5 \mathrm{~g}$ ) were reared in the INRA experimental fish farm (Donzacq, Landes, France) in four 10001 fiber glass tanks $\left(2 \times 2 \mathrm{~m}\right.$; water temperature $17 \pm 1{ }^{\circ} \mathrm{C}$; oxygen level $\left.8.5 \mathrm{ppm}\right)$. Duplicate groups were 
1 hand-fed to visual satiety twice daily the respective diets over 157 days. Fish were group weighed

2 every three weeks to follow growth and feed intake. At the end of the growth trial, different growth and feed utilisation parameters were calculated.

\subsection{Body and fillet quality determinations}

After the final weighing, fish were kept unfed for two days, were cold stunned, slaughtered by a blow on the head and stored on ice at $1{ }^{\circ} \mathrm{C}$. All fish were weighed and the following measurements made using an orthometric meter: total and standard length $(\mathrm{cm})$, head length $(\mathrm{cm})$, and maximum height $(\mathrm{cm})$. From linear and weight measures, morphometric indexes, as condition factor $=\left(100 \mathrm{x}\right.$ body weight $/$ total length $\left.^{3}\right)$, agility index (distance between caudal plane and maximum height plane / maximum height), cranial index (head length / total length), relative profile (maximum height / total length), were computed. On the whole, 80 fish (40 fish per diets) were completely dissected to weigh the main body components and to calculate the relative weights $(\%$ of body weight) of fins, gills, head, fillets, viscera, digestive tract, mesenteric fat, liver, and dressed weight. The fillet yield (\%) was computed as twice the right fillet weight. The hepato-somatic index $(\mathrm{HSI})=[100 \mathrm{x}$ (liver weight $/$ body weight) $]$ and the viscero-somatic index (VSI) $[100 \mathrm{x}$ (total viscera weight / body weight)] were also computed.

During dissection, we observed the presence of 21 diploid trout $(12 \%$ of fish, $n=12$ FM and $n=9$ PP) in an advanced state of sexual maturity, therefore the corresponding data were removed and not considered in the statistical analysis.

39 fillets and 11 livers were vacuum packed and stored on dry ice prior to chemical composition analysis: moisture, crude protein, ash and phosphorus according to AOAC (1995) and total lipids according to Folch et al. (1957). Fatty acid composition of fillets ( $n=18$ FM and $n=21$ PP) and livers $(\mathrm{n}=5 \mathrm{FM}$ and $\mathrm{n}=6 \mathrm{PP}$ ) was analysed by quantitative gas cromatography (utilising C23:0 as internal standard) and total cholesterol (Boach et al., 1988) and malonaldehyde-TBA complex (Raharjo et al. 1993), were determined in the fillets. 


\subsection{Instrumental colour measurement of fillets}

On 75 intact right fillets (FM n=36 and PP n=39), withdrawn at the moment of the analysis from whole fish stored at $1{ }^{\circ} \mathrm{C}$, colorimetric measurements were made using a CR-200 Chroma Meter (Minolta, U. K.) at three sites (dorsal, ventral and caudal) and each measure was replicated twice. Data were expressed using the L* a* b* system, representing lightness, redness and yellowness as indicated by the CIE (1976); in addition, the values of chroma $\left[\sqrt{ }\left(a^{*^{2}}+b^{*^{2}}\right)\right]$, which defines the saturation of colour and the angle of hue $\left[\tan ^{-1}\left(b^{*} / a^{*}\right)\right]$ were calculated.

\subsection{Sensory evaluation}

Sensory evaluation on cooked fillet was made after 5 days post mortem on fillets withdrawn from whole fish stored with ice at $1{ }^{\circ} \mathrm{C}$. The epaxial portion of each fillet with skin was divided into 5 portions, wrapped in a special microwave oven paper and cooked in a microwave oven (Moulinex Optiquick Compact), at 500 watt for 70 seconds. A trained panel consisting of 10 judges evaluated the fillets in air-conditioned individual boxes designed for sensory analysis (ISO, 1988) by triangular and descriptive tests. The triangular test (ISO, 1983) and the descriptive tests were replicated twice. As the triangular test was able to discriminate between diets, it was followed by the descriptive test to evaluate the following sensory attributes: odour (intensity, rancid), flavour (intensity, fresh, sweet, fresh oil, metallic, fat, slight herring like, rancid), hardness, compactness, juiciness and roughness (mouth feeling of fibres). All attributes were evaluated on a continuous intensity scale, going from 1 (no intensity) to 9 (high intensity), using a computerised system for direct recording (PSA System III Oliemans Punter \& Partners $\left.{ }^{\circledR}\right)$.

\subsection{Statistic analysis}

Data were analysed by a one way ANOVA (diet). The fatty acid profile was analysed also including the total fillet lipid content in the model. As the malonaldehyde content was determined at 
1 different time after the death, the statistical analysis of this parameter was made including in the model the number of days post-mortem. As colour measurements were made at different time intervals after death and in different sites of the fillet, the statistical analysis of this parameter was made including in the model the diet as a fixed factor, with the days, the site and the interaction site $\mathrm{x}$ diet as variable. The sensory evaluation was computed by Generalised Procrustes Analysis (GPA) (Gower, 1975) carried out with Senstool (Oliemans Punter \& Partners $\left.{ }^{\circledR}\right)$, to take into account the variation among judges, then the data were analysed by a one way ANOVA to evaluate the effect of diet on all the descriptors.

\section{Results}

\section{$\underline{3.1 \text { Growth performance and body traits }}$}

Changes in mean body weights of both groups over the entire period is presented in figure 1 .

Numerical data on growth, feed intake and utilisation are reported in table 4 . While feed intake did not differ between the two fish groups, significant differences were observed for all other parameters, all being higher in trout fed diet FM than in those fed diet PP.

As reported in table 5 trout fed diet FM reached a significantly higher final body weight ( 800 vs 664 g ) and total length compared to those fed diet PP. Trout fed diet PP had consequently a higher condition factor (1.27 vs 1.22 ). We did not observe any differences in agility index, cranial index and relative profile. Trout fed diet FM had significantly lower relative weight of gills, while fins, head, filleting remnant and digestive tract incidences did not differ. The hepato-somatic index was higher in trout fed diet FM than in those fed diet PP. No differences were observed in fillets percentage between the fish groups, while the significantly higher $(\mathrm{P}<0.01)$ viscero-somatic index observed in trout fed diet PP, was principally due to higher mesenteric fat percentage leading to lower dressed weight yield. 


\subsection{Chemical composition}

Concerning fillet composition (table 6), moisture and phosphorous contents were similar in both groups, while trout fed diet PP had slightly higher protein and ash and a lower lipid percentage and cholesterol content than trout fed diet FM. No difference in malonaldehyde content was observed between groups. As regards liver, only the moisture and crude protein percentages were significantly different, with trout fed diet PP showing higher values in comparison to trout fed diet FM.

The fatty acid composition of fillets is reported in table 7 , expressed as percentages of total fatty acids and as g / $100 \mathrm{~g}$ fillet. Saturated (SFA), monounsaturated (MUFA) and polyunsaturated n-3 (PUFA n-3) fatty acids and the $n-3 / n-6$ ratio were significantly higher in trout fed diet FM, while polyunsaturated n-6 (PUFA n-6) fatty acids were significantly higher in trout fed diet PP. As regards individual fatty acids, the main difference observed was the higher incidence and content of linoleic acid in PP fillet in comparison to FM one, while there was no difference for the eicosapentaenoic and the docosahexaenoic acid levels. The liver fatty acid profile (table 8) was also characterised by the higher incidences and quantities of linoleic acid and n-6 PUFA in trout fed diet PP in comparison to that in the liver of trout fed diet FM. However, there was no difference between groups as regards total n-3 PUFA levels.

\section{$\underline{3.3 \text { Fillet colour }}$}

As regards fillet colour, some differences were observed at each of the three points of measure. In dorsal and caudal sites, the values of redness, of yellowness and of hue were different between the diets (Table 9). At all the considered sites (dorsal, ventral and caudal) the dietary treatments did not result in any significant difference for chroma or lightness except for the ventral site. Statistical analysis of differences between sites indicated a significant site effect for all the colour parameters. 
$2 \quad 3.4$ Sensory analysis

The triangular test made at 5 days after death indicated differences in organoleptic

\section{Discussion}

Growth rates of both groups were high, although in spite of the supplementation with synthetic amino acids to improve amino acid balance, the total substitution of the fish meal with a plant protein mixture did not lead to equivalent final weights at the end of the nearly 6 months growth trial. It is worth noting that the growth rates became significantly different only after 12 weeks (Figure 1), confirming the need for long term studies. Since feed intakes did not differ between groups, feed and protein efficiencies were also reduced. Whether this is due to inadequate amino acid supply to meet the high growth rates over the long run or due to accumulative effects of unidentified anti-nutritional factors remains to be investigated. It has been suggested that the length of a feeding trial can bring out growth differences in a significant manner (Weatherup and McCraken, 1999). Given the long term study as undertaken here, it is also difficult to compare data from literature, where the studies have been of shorter duration. However, the main objective of this work was to obtain trout with a final body weight of commercial size, and to compare the effects of dietary protein sources on flesh quality parameters. 
One of the problems related to plant protein ingredients is the relatively high carbohydrate contents in these ingredients which are generally not well digested by salmonids (Singh and Nose, 1967) but this can be improved by technological treatments (Luquet and Bergot, 1976; Bergot, 1993). In fact, the starch content as measured in diet PP was lower that in diet FM, mainly due to the inclusion of extruded whole wheat which is generally known to have high starch digestibility. Plant ingredients contain varying levels of non-starch polysaccharides (Malathi and Devegowda, 2000) whose possible adverse effects are little known in fish (Francis et al. 2001). This needs further exploration.

It is quite possible that other ANFs could be responsible for the poor growth rate observed in the trout fed the plant protein mixture diet. Preliminary control has shown that the anti-trypsic factors were low. We also found the phytoestrogen (genistein and daidzein) contents to be extremely small (Bennetau - Pelissero et al., 2003).

As regards body morphological traits, mean condition factor value observed in both groups of trout (1.2) was slightly lower than the value of 1.4 reported by Bonnet et al. (1999) in triploid trout with a mean body weight of $837 \mathrm{~g}$. Trout fed diet PP, even with $20 \%$ lower body mass, were characterised by a higher condition factor, possibly mainly due to the high mesenteric fat content, suggesting higher fat synthesis and deposition. But, trout fed diet based on fish meal had a higher fillet fat content, possibly related to the higher body weight. The possible metabolic or endocrine mechanisms involved in such differences in tissue lipid deposition are under scrutiny. One possible reason is the higher supply of some of the dispensable amino acids (DAA) such as glutamic acid in excess in the diet PP.

As is well known (Watanabe, 1982; Sargent, 2002), dietary fatty acid composition strongly influenced flesh fatty acid composition. While it is common to see such changes when dietary fatty acid profiles are modified through changes in dietary lipid sources, there is little information as 
1 regards the effects of changes in fatty acid profiles as affected by dietary protein sources. Indeed,

total replacement of fish meal by plant protein ingredients modifies the fatty acid profiles to a certain extent (table 3) with the consequent changes seen in liver and muscle fatty acid profiles. Fillet of trout fed diet FM was richer in saturated fatty acids, monoenes, and n-3 PUFAs and those of fish fed diet PP markedly richer in n-6 PUFAs, above all in C18:2 n-6. The differences in fillet fatty acid profiles of the two groups of trout were confirmed even when corrected for differences in total lipid content of fillets found between the two groups. Only the difference in C22:5 n-3, higher in fillet of fish fed fish meal diet disappeared, indicating that it was strictly related to the different total lipid content. The quantitative differences in C14:0, C16:0, C18:0, C20:5 n-3, C22:1 n-11, C22:5 n-3, C22:6 n-3, SFA, MUFA, and PUFA n-3 were due to the higher lipid content in FM, while the higher content of PUFA n-6 in PP fillet was confirmed also when evaluated at the same lipid content. This result was consistent with data obtained by Gomes et al. (1993), they observed an increased level of n-6 series fatty acids in muscle of rainbow trout fed diets with an increasing level $(5,10,15$ and $45 \%)$ of colzapro. It is reassuring to note that, at the same lipid level, the content in eicosapentaenoic (EPA) and in docosahexaenoic (DHA) acids did not show differences in the two groups of trout. Pereira et al. (1998) reported that when broodstock rainbow trout were fed diets in which fish meal was totally replaced by plant protein sources, egg fatty acid profiles were modified reflecting dietary changes, still maintaining high levels of long chain n-3 PUFAs. We see here that despite increases in n-6 fatty acids, the total replacement of fish meal with plant protein sources did not influence the quantity of n-3 PUFA considered as the most interesting in terms of human health. In an earlier study, Lopez- Bote et al. (2001) found that under conditions of forced peroxidation in vitro, muscle of fish fed diets containing fish meal as the main source of protein showed higher susceptibility to peroxidation than muscle from fish fed plant protein based diets. This is in contrast to observations made here, where we did not see any differences in the levels of malonaldehyde. Whether this is due to methodological differences remains to be verified. 
1 As regards pigmentation, which remains a major flesh quality attribute for salmonids, the 2 differences in data obtained through instrumental measurements were consistent with the observation of the panellists during the panel test, when they recognised as different the two PP and FM fillet first of all by the colour. In the study by Kaushik et al. (1995), there was also a distinction based on this colour attributes between trout fed fish meal or soy protein concentrate; but this was largely due to the fact that the diets did not contain any added astaxanthin, except that which was supplied by the fish meal. Dietary soybean meal does not seem to interfere with astaxanthin absorption or deposition (Bjerkeng et al. 1997). Our results show in all the three sites a higher value of yellowness in trout fed diet PP and a higher redness in trout fed diet FM. The differences observed here could partially be attributed to the presence of corn gluten meal in diet PP as suggested by Hardy (1996). Indeed, in an earlier work, we have found that even in the presence of adequate amount of astaxanthin in the diet, muscle colour attributes are modified and muscle retention of astaxanthin is lowered in the presence of very high levels of corn gluten meal (Kaushik et al., 2002). Another interesting point is the consistency in the variability of the intra-fillet colour. There was no interaction between the site and the diet, indicating that all the fillets, presented the same colour difference in the different sites analysed. The highly $(\mathrm{P}<0.01)$ significant effect of the measurement location is in agreement with literature data (Choubert, 1997). Nickell and Bromage (1998) proposed that this was due to the difference in fillet thickness between the examined regions, and that a relation between muscular fibre size and astaxanthin retention would be implied.

In agreement with Kaushik et al. (1995), who reported that the panellists in the sensory analysis were able to distinguish two groups of trout fed two different diets, fed either $100 \%$ fish meal diet or a $100 \%$ of soy protein concentrate based diet, the sensory analysis made here indicated organoleptic differences between the trout fed the two diets.

Juiciness is an important contributor to eating quality although the relationship between this food characteristic and the objective measurement is not completely clear (Ruiz-Carrascal et al. 2000). The higher juiciness and odour intensity of trout fed diet FM perceived at 5 days after death, can be 
1 related to the different fatty acid profile and consequent minor changes in lipid oxidative status, as

2 reported by Johansson et al. (2000). The presence of a higher quantity of intramuscular fat in FM fillet could have also stimulated the production of saliva resulting in a higher sensation of juiciness (Johansson et al. 1991).

Summing up, the total replacement of fish meal by a mixture of plant protein sources and adequately balanced with essential amino acids, affects growth of rainbow trout in the long term, inducing changes in body traits, chemical composition and fatty acid profile of fillets and led to changes in some organoleptic properties of flesh.

\section{Acknowledgements}

The authors thank Denise Blanc, Christiane Vachot, Frédéric Vallée and Antonio Bonelli for their technical support, and the staff of the INRA Experimental Fish Farm at Donzacq (Yves Hontang, Frédéric Terrier and Franck Sandres) for the care and feeding of the fish. This research was financed by the European project QLRT-1999-30068 "Perspectives of plant protein use in aquaculture".

\section{References}

A.O.A.C., 1995. Ass. Off. Anal. Chem. Arlington, VA, USA.

Aoki, H.,Shimazu, H.,Fukushige, T.,Akano, H.,Yamagata, Y.Watanabe, T. 1996. Flesh quality in red sea bream fed with diet containing a combination of different protein sources as total substitution for fish meal. Bull. Fish. Res. Inst. Mie., 6: 47-54.

Ballestrazzi, R., Lanari, D., D’Agaro, E., Mion, A., 1994. The effect of dietary protein level and source on growth, body composition, total ammonia and reactive phosphorus excretion of growing sea bass (Dicentrarchus labrax). Aquaculture, 127, 197-206. 
1 Barrias, C., Oliva-Teles, A., 2000. The use of locally produced fish meal and other dietary manipulations in practical diets for rainbow trout Oncorhynchus mykiss (Walbaum). Aquacult. Res., 31, 213-218.

Bennetau - Pelissero, C., Lamothe, V., Shinkaruk - Poix, S., Kaushik, S. J., 2003. Screening estrogenic activity of plant and food extracts using in vitro trout hepatocyte cultures. Phytochemical Analysis, In Press.

Bergot, F. 1993. Digestibility of native starches of various botanical origins by rainbow trout. (Oncorhynchus mykiss). In: S.J. Kaushik and P. Luquet (Editors), Fish Nutrition in Practice. Proc. IV Int. Symp. Fish Nutrition and Feeding, Les Colloques INRA, Paris, No. 61, pp. 857865.

Bjerkeng, B., Refstie, S., Fjalestad, K. T., Storebakken, T., Rodbotten, M.Roem, A. J. 1997. Quality parameters of the flesh of Atlantic salmon (Salmo salar) as affected by dietary fat content and full-fat soybean meal as a partial substitute for fish meal in the diet. Aquaculture, 157(34): 297-309.

Boach, C. E., Rhee, K. S., Cross, H. S., Ono, K., 1988. Assessment of methodologies for colorimetric cholesterol assay of meats. J. Food Sci., 53, 1642-1644.

Bonnet, S., Haffray, P., Blanc, J. M., Vallée, F., Vauchez, C., Fauré, A., Fauconneau, B., 1999. Genetic variation in growth parameters until commercial size in diploid and triploid freshwater rainbow trout (Oncorhynchus mykiss) and seawater brown trout (Salmo trutta). Aquaculture, 173, 359-375.

Burel, C., Boujard, T., Corraze, G., Kaushik, S.J., Boeuf, G., Mol, K.A., Van Der Geyten, S., Kuhn, E. R., 1998. Incorporation of high levels of extruded lupin in diets for rainbow trout (Oncorhynchus mykiss): nutritional value and effect on thyroid status. Aquaculture, 163, 325345. 
1 Burel, C., Boujard, T., Tulli, F., Kaushik, S. J., 2000. Digestibility of extruded peas, extruded lupin, and rapeseed meal in rainbow trout (Oncorhynchus mykiss) and turbot (Psetta maxima). Aquaculture, 188, 285-298.

Carter, C. G. and Hauler, R. C., 2000. Fish meal replacement by plant meals in extruded feeds for Atlantic salmon (Salmo salar). Aquaculture, 185: 299-311.

Choubert, G., 1997. Colour measurements, using the CIELCH colour space, of muscle of rainbow trout, Oncorhynchuss mykiss (Walbaum), fed astaxanthin: effects of family, ploidy, sex, and location of reading. Aquacult. Res., 28: 15-22.

CIE (Commission Internationale de L'Eclairage), 1976. Colorimetry. Pub. N 15, Bureau Central de la CIE, Vienna, Austria.

Cowey, C. B., 1993. Some effects of nutrition on flesh quality of cultured fish. In: S.J. Kaushik and P. Luquet (Editors), Fish Nutrition in Practice. Proc. IV Int. Symp. Fish Nutrition and Feeding, Les Colloques INRA, Paris, No. 61, pp. 227-236.

Dorsa, W. J., Robinette, H. R., Robinson, E. H., Poe, W. E., 1982. Effects of dietary cottonseed meal and gossypol on growth of young channel catfish. Trans. Am. Fish. Soc., 3: 651-655.

Folch, J., Lees, M., Stanley, H.S., 1957. A simple method for the isolation and purification of total lipids from animal tissues. J. Biol. Chem., 226: 497-509.

Forster, I., Higgs, D.A., Dosanij, B. S., Rowshandeli, M., Parr, J., 1999. Potential for dietary phytase to improve the nutritive value of canola protein concentrate and decrease phosphorus output in rainbow trout (Oncorhynchus mykiss) held in $11^{\circ} \mathrm{C}$ fresh water. Aquaculture, 179: $109-125$.

Fowler, L. G., 1980. Substitution of soybean and cottonseed products for fish meal in diet fed to chinook and coho salmon. Prog. Fish. Cult., 42: 87-91.

Francis, G., Makkar, P.S., Becker, K., 2001. Antinutritional factors present in plant-derived alternate fish feed ingredients and their effects in fish. Aquaculture, 199: 197-227. 
1 Geri, G., Gualtieri, M., Lupi, P., Parisi, G., Dell'Agnello, M., Mecatti, M., 1994. Evolution morphologique des téléostéens pendant la croissance: 1. Proposition d'une méthode d'étude. In: Kestemont, P., Muir, J., Sévila, F., Williot, P. (Eds.), Measures for Success: Metrology and Instrumentation in Aquaculture Management. Proceedings of Bordeaux Aquaculture '94, 23-25 March 1994, Bordeaux, France, CEMA-GREF Editions, Gap, France, pp. 239-243.

Gomes, E. F. and Kaushik, S. J., 1990. Potential use of triticale in diets for rainbow trout: effects of dietary levels and incidence of cooking. Ann. Zootech., 39: 63-73.

Gomes, E.F., Corraze, G., Kaushik, S.J., 1993. Effects of dietary incorporation of a co-extruded plant protein (rapeseed and peas) on growth, nutrient utilization and muscle fatty acid composition of rainbow trout (Oncorhynchus mykiss). Aquaculture, 113: 339-353.

Gomes, F. E., Rema, P., Kaushik, S. J., 1995. Replacement of fish meal by plants proteins in the diet of rainbow trout (Oncorhynchus mykiss): digestibility and growth performance. Aquaculture, 130: 177-186.

Gower, J.C., 1975. Generalised Procrustes Analysis. Psychometrika, 40: 33-51.

Hardy, R.W., 1995. Current issues in salmonid nutrition. In: Nutrition and Utilization Technology in Aquaculture (ed. by C. Lim and D.J. Sessa), pp. 26-35. AOCS Press, Campaign, IL, USA.

Hardy, R.W., 1996. Alternate protein sources for salmon and trout diets. Anim. Feed Sci. Techn. $59,71-80$.

Hardy, R.W., 1999. Collaborative opportunities between fish nutrition and other disciplines in aquaculture: an overview. Aquaculture, 177: 217-230.

Higgs, D.A., Prendergast, A.F., Dosanjh, B.S., Beames, R.M., Deacon, G., 1995. Potential for reducing cost of salmon production by dietary inclusion of novel rapeseed / canola protein products. Proceedings of the $9^{\text {th }}$ Int. Rapeseed Congr., Rapeseed Today and Tomorrow (Murphy, D. ed.), Vol. 1, pp 133-138. GCIRC, Cambridge, UK.

ISO, 1983. 4120-1983. Sensory analysis - Triangular test. International Organization for Standardization. Geneva, Switzerland. 
1 ISO, 1988. 8589-1988. Sensory analysis - General guidance for the design of test rooms. International Organization for Standardization. Geneva, Switzerland.

Johansson, L., Kiessling, A., Carlsson, R., 1991. Eating quality and growth of rainbow trout (Oncorhynchus mykiss) on feed with different admixtures of leaf nutrient concentrate. J. Sci. Food Agric., 57, 217-234.

Johansson, L., Kiessling, A., Kiessling, K. H., Berglund, L., 2000. Effects of altered ration levels on sensory characteristics, lipid content and fatty acid composition of rainbow trout (Oncorhynchus mykiss). Food Qual. Pref., 11: 247-254.

Kaushik S.J., 1990. Use of alternative protein sources for the intensive rearing of carnivorous fishes. In: Mediterranean Aquaculture, (R. Flos, L. Tort \& P. Torres, eds), Ellis Horwood, UK. pp 125-138.

Kaushik, S. J., Mambrini, M., 1994. Nutrition azotée des poissons: Remplacement partiel ou total de la farine de poissons. La pisciculture française, 118: 12-20.

Kaushik, S.J., Cravedi, J.P., Lalles, J.P., Sumpter, J., Fauconneau, B., Laroche, M., 1995. Partial or total replacement of fish meal by soybean protein on growth, protein utilization, potential estrogenic or antigenic effects, cholesterolemia and flesh quality in rainbow trout (Oncorhynchus mykiss). Aquaculture, 133: 257-274.

Kaushik, S.J., Corraze, G., Choubert, G., 2002. Effet de la source de protéine alimentaire sur la pigmentation de la truite arc-en-ciel (Oncorhynchus mykiss). Proc. 4è Journée INRAIFREMER Nutrition des Poissons, Bordeaux Aquaculture, Bordeaux, 20 sept 2002, 4 pp.

Kissil, G. Wm, Lupatsch, I., Higgs, D. A., Hardy, R. W., 2000. Dietary substituition of soy and rapeseed protein concentrates for fish meal, and their utilization in gilthead seabream Spaurus aurata L.. Aquac. Research, 31: 595-601.

Lopez-Bote, C. J., Diez, A., Corraze, G., Arzel, J., Alvarez, M., Dias, J., Kaushik, S. J. Bautista, J. M., 2001. Dietary protein source affects the susceptibility to lipid peroxidation of rainbow 
trout (Oncorhynchus mykiss) and sea bass (Dicentrarchus labrax) muscle. Animal Science, 73: 443-449.

Luquet, P.Bergot, F. 1976. Efficiency of various treatments of cereals. 7. Utilization of pelleted, flaked, popped and extruded maize in the feed of rainbow trout. Ann. Zootech., 25: 63-69.

Malathi, V., Devegowda, G., 2000. In vitro evaluation of nonstarch polysaccharide digestibility of feed ingredients by enzymes. Poultry Sci., 80: 302-305.

Médale, F., Boujard, T., Vallée, F., Blanc, D., Mambrini, M., Roem, A., Kaushik, S.J., 1998. Voluntary feed intake, nitrogen and phosphorus losses in rainbow trout (Oncorhynchus mykiss) fed increasing dietary levels of soy protein concentrate. Aquat. Living Resour., 11: 239-246.

Morales, A.E., Cardenete, G., De la Higuera, M., Sanz, A., 1994. Effects of dietary protein source on growth, feed conversion and energy utilization in rainbow trout, Oncorhynchus mykiss. Aquaculture, 124: 117-126.

Murai, T., 1992. Protein nutrition of rainbow trout. Aquaculture, 100: 191-207.

Naylor, L. R., Goldburg, J., Primavera, H. J., Kautsky, N., Beveridge, M. C. M., Clay, J., Folke, C., Lubchenco, J., Mooney, H., Troell, M., 200. Effect of aquaculture on world fish supplies. Nature, 405: 1017-1024

New, M. B., Wijkstroem, U. N., 2002. Use of fishmeal and fish oil in aquafeeds. Further thoughts on the fishmeal trap. FAO Fish. Circ., 975, 61 p.

Nickell, D. C., Bromage, N. R., 1998. The effect of timing duration of feeding astaxanthin on the development and variation of fillet colour and efficiency of pigmentation in rainbow trout (Oncorhynchus mykiss). Aquaculture, 169: 233-246.

NRC, 1993. Nutrient Requirements of Fish. National Academy Press, Washington, DC.

Oliva-Teles, A., Gouveia, A.J., Gomes, E., Rema, P., 1994. The effect of different processing treatments on soybean meal utilization by rainbow trout, Oncorhynchus mykiss. Aquaculture, 124: 343-349. 
1 Pereira, J. O. B.,Reis-Henriques, M. A.,Sanchez, J. L.Costa, J. M. 1998. Effect of protein source on the reproductive performance of female rainbow trout, Oncorhynchus mykiss (Walbaum). Aquacult. Res., 29 (10):751-760.

Raharjo, S., Sofos, J. N., Schmidt, G.R., 1993. Solid-phase acid extraction improves thiobarbituric acid method to determine lipid oxidation. J. Food Sci., 58: 921-924.

Refstie, S., Storebakken, T., Helland, S.J., 1997. Adaptation to soybean meal in diets for rainbow trout, Oncorhynchus mykiss. Aquaculture, 153: 263-272.

Refstie, S., Korsoen, O.J., Storebakken, T., Baeverfjord, G., Lein, I., Roem, A.J., 2000. Differing nutritional responses to dietary soybean meal in rainbow trout (Oncorhynchus mykiss) and Atlantic salmon (Salmo salar). Aquaculture, 190: 49-63.

Riche, M., Brown, P.B., 1999. Incorporation of plant protein feedstuff into fish meal diets for rainbow trout increases phosphorus availability. Aquacult. Nutr., 5: 101-105.

Robaina, L., Izquierdo, M. S., Moyano, F. J., Socorro, J., Vergara, J. M. , Montero, D., FernàndezPalacios, H., 1995. Soybean and lupin seed meals as protein sources in diets for gilthead seabream (Spaurus aurata): nutritional and histological implications. Aquaculture, 130: 219233.

Ruiz-Carrascal, J., Ventanas, J., Cava, R., Andrès, A. I., Garcìa, C., 2000. Texture and appearance of dry cured ham as affected by fat content and fatty acid composition. Food Res. Int., 33: 91-95.

Sanz, A., Morales, A. E., de la Higuera, M., Cardenete, G., 1994. Sunflower meal compared with soybean meal as partial substitutes for fish meal in rainbow trout (Oncorhynchus mykiss) diets: protein and energy utilization. Aquaculture, 128: 287-300.

Sargent, J.R., Tocher, D.R., Bell, G.J., 2002. The lipids. In: J.E. Halver, R. Hardy (Eds). Fish Nutrition, Third Edition. Academic Press, Elsevier Science, pp. 181-257.

Singh, R. P., Nose, T., 1967. Digestibility of carbohydrates in young rainbow trout. Bull. Freshwater Fish. Res. Lab., 17: 21-25. 
Smith, R. R., Kincaid, H. L., Regenstein, J. M.Rumsey, G. L. 1988. Growth, carcass composition, and taste of rainbow trout of different strain fed diets containing primarily plant or animal protein. Aquaculture, 70:. 309-321.

Tacon, A. G. J., Haaster, J. V., Featherstone, P. B., Kerr, K., Jackson, A. J., 1983. Studies on the utilization of full-fat and solvent extracted soybean meal in a complete diet for rainbow trout. Bull. Jpn. Soc. Sci. Fish., 49: 1473-1443.

Teskeredzic, Z., Higgs, D. A., Dosanjh, B. S., McBride, J. R., Hardy, R. W., Beames, R. M., Jones, J. D., Simell, M., Vaara, T., Bridges, R. B., 1995. Assessment of undephytinized and dephytinized rapeseed protein concentrate as sources of dietary protein for juvenile rainbow trout (Oncorhynchus mykiss). Aquaculture, 131: 261-277.

Vielma, J., Makinen, T., Ekholm, P., Koskela, J., 2000. Influence of dietary soy and phytase levels on performance and body composition of large rainbow trout (Oncorhynchus mykiss) and algal availability of phosphorus load. Aquaculture, 183: 349-362.

Watanabe, T., 1982. Lipid nutrition in fish. Comp. Biochem. Physiol. 73 B, 3-15.

Watanabe, T., Verakunpiriya, V., Watanabe, K., Viswanath, K., Satoh, S., 1998. Feeding of rainbow trout with non-fish meal diets. Fisheries Sci., 63: 258-266.

Watanabe, T., Pongmaneerat, J., 1993. Potential of soy bean as protein source in extruded pellets for rainbow trout. Nippon Suisan Gakkaishi, 58: 1415-1423.

Weatherup, R.N., McCraken, K.J., 1999. Changes in rainbow trout, Oncorhynchus mykiss (Walbaum), body composition with weight. Aquacult. Res., 30: 305-307. 
Table1. Ingredient and chemical composition of the experimental diets.

\begin{tabular}{lcc}
\hline & FM & PP \\
\hline Ingredients (g/kg) & & \\
Fish meal (Herring, Norway) & 638.0 & 0.0 \\
Corn gluten meal & 0.0 & 232.4 \\
Wheat gluten & 0.0 & 200.0 \\
Extruded peas (Aquatex, France) & 0.0 & 163.3 \\
Rapeseed meal (Primor 00, France) & 0.0 & 100.0 \\
Extruded whole wheat & 203.4 & 0.0 \\
Fish oil & 128.6 & 158.7 \\
Binder (Na Alginate) & 10.0 & 10.0 \\
Mineral premix 1 & 10.0 & 10.0 \\
Vitamin premix 1 & 10.0 & 10.0 \\
CaHPO $2 \mathrm{H}_{2} 0$ & 0.0 & 40.0 \\
Amino acid mix ${ }^{2}$ & 0.0 & 75.7 \\
Astaxanthin ${ }^{3}$ & 0.01 & 0.01 \\
& & \\
Analytical composition & & \\
Dry matter (DM, g/kg) & 944 & 916 \\
Protein (g/kgDM) & 515 & 486 \\
Lipid (g/kg DM) & 197 & 192 \\
Starch (g/kg DM) & 138 & 105. \\
Ash (g/kg DM) & 76 & 59 \\
Phosphorus (g/kg DM) & 19 & 13 \\
Energy (kJ/g DM) & 22.7 & 23.6 \\
\hline
\end{tabular}

${ }^{1}$ According to NRC (1993)

${ }^{2}$ Arg: 12.5; His: 4.0; Lys: 27.6; DL-Mét: 4.1; Trp: 2.7; Thr: 8.3; Ile: 7.1; Val:9.4

${ }^{3}$ Carophyll Pink ${ }^{\circledR}$, Hoffman LaRoche, Basel, Switzerland 
Table 2. Amino acid composition (g / $100 \mathrm{~g} \mathrm{DM})$ of the experimental diets fed to rainbow trout

2

3

\begin{tabular}{lrc}
\hline Amino acid & Diet FM & Diet PP \\
\hline ARG & 3.6 & 3.3 \\
LYS & 4.0 & 3.5 \\
HIS & 0.9 & 1.3 \\
ILE & 1.8 & 2.2 \\
LEU & 3.4 & 4.2 \\
VAL & 2.2 & 2.8 \\
MET & 1.2 & 1.0 \\
PHE & 1.7 & 2.0 \\
THR & 2.4 & 2.3 \\
TYR & 1.4 & 1.6 \\
Asp & 4.3 & 2.1 \\
Glu & 7.5 & 12.9 \\
Ser & 2.1 & 2.1 \\
Pro & 2.1 & 3.3 \\
Gly & 3.1 & 1.4 \\
Ala & 3.0 & 2.0 \\
Sum AA & 44.7 & 46.7 \\
Sum IAA & 22.6 & 23.2 \\
Sum DAA & 22.1 & 23.5 \\
\hline
\end{tabular}


Table 3 . Total lipids ( $\%$ on wet weight) and fatty acid $^{1}(\%$ of total fatty acids) composition of FM and PP diets.

\begin{tabular}{lcc}
\hline & FM & PP \\
\hline Lipids \% & 18.12 & 18.19 \\
C14:0 & 6.3 & 6.0 \\
C16:0 & 14.3 & 14.1 \\
C16:1 n-7 & 5.4 & 4.7 \\
C18:0 & 1.8 & 1.7 \\
C18:1 n-9 & 13.3 & 14.8 \\
C18:2 n-6 & 2.2 & 10.6 \\
C18:3 n-3 & 1.1 & 1.6 \\
C18:4 n-3 & 3.4 & 3.2 \\
C20:1 n-9 & 9.1 & 7.3 \\
C20:5 n-3 & 11.0 & 9.3 \\
C22:1 n-11 & 12.5 & 11.1 \\
C22:6 n-3 & 12.7 & 10.0 \\
& & \\
$\Sigma$ SFA & 23.3 & 22.6 \\
$\Sigma$ MUFA & 41.9 & 38.8 \\
$\Sigma$ PUFA n-6 & 3.3 & 11.5 \\
$\Sigma$ PUFA n-3 & 30.3 & 25.8 \\
n3 / n6 ratio & 9.2 & 2.3 \\
\hline
\end{tabular}

${ }^{1}$ The fatty acids C12:0, C15:0, C16:2 n-4, C16:3 n-3, C16:4 n-1, C17:0, C18:2 n-4, C18:3 n-4, C18:3 n-6, C20:0, C20:1 n-7, C20:2 n-6, 20:3 n-3, C20:3 n-6, C 20:4 n-3, C20:4 n-6, C22:1 n-9, C21:5 n-3, C22:4 n-6, C22:5 n-6, in percentage less than $1 \%$, were considered in the composite fractions but not reported in the table for brevity. 
Table 4. Growth performance, feed intake and feed efficiency of rainbow trout fed the FM and PP diets ${ }^{1}$.

\begin{tabular}{lcc}
\hline & FM & PP \\
\cline { 2 - 3 } Initial body weight (IBW) $(\mathrm{g})$ & $163.0 \pm 4.2$ & $162.0 \pm 2.8$ \\
Final body weight (FBW) (g) & $844.9 \pm 29.8^{\mathrm{a}}$ & $666.2 \pm 14.1^{\mathrm{b}}$ \\
Specific growth rate (SGR) (\%) & $1.05 \pm 0.01^{\mathrm{a}}$ & $0.90 \pm 0.03^{\mathrm{b}}$ \\
Daily growth index (DGI) $(\%)$ & $2.54 \pm 0.04^{\mathrm{a}}$ & $2.09 \pm 0.06^{\mathrm{b}}$ \\
Feed intake (FI) (DM / kg ABW $\left./ \mathrm{d}^{-1}\right)$ & $8.20 \pm 0.28$ & $8.19 \pm 0.06$ \\
Feed efficiency (FE) & $1.07 \pm 0.01^{\mathrm{a}}$ & $0.95 \pm 0.02^{\mathrm{b}}$ \\
Protein efficiency ratio (PER) & $2.13 \pm 0.03^{\mathrm{a}}$ & $1.96 \pm 0.03^{\mathrm{b}}$ \\
\hline
\end{tabular}

\footnotetext{
${ }^{1}$ Means are indicated with standard deviation. Different superscript letters in the same row indicate significant statistical differences $(\mathrm{a}, \mathrm{b}: \mathrm{P}<0.05)$.

${ }^{*} \mathrm{ABW}=$ average body weight.

$\mathrm{SGR}=100 \times[(\ln \mathrm{FBW}-\ln \mathrm{IBW}) /$ duration $)]$

$\mathrm{DGI}=100 \times\left[(\mathrm{FBW})^{1 / 3}-(\mathrm{IBW})^{1 / 3}\right] /$ duration;

$\mathrm{ABW}=$ average body weight

$\mathrm{FE}=$ wet weight gain / dry feed intake

PER = wet weight gain / crude protein intake.
} 
Table 5. Body morphological traits in trout fed diets based on fish meal (FM) or on a mixture of plant protein sources (PP) ${ }^{1}$.

\begin{tabular}{lccccc}
\hline & $\mathrm{N}^{\circ}$ & $\mathrm{FM}$ & $\mathrm{N}^{\circ}$ & $\mathrm{PP}$ & rsd \\
\hline Body morphological traits & & & & & \\
Body weight (g) & 73 & $800.27^{\mathrm{A}}$ & 77 & $663.50^{\mathrm{B}}$ & 148.72 \\
Total length (cm) & 73 & $40.16^{\mathrm{A}}$ & 77 & $37.21^{\mathrm{B}}$ & 2.48 \\
Condition factor & 73 & $1.22^{\mathrm{B}}$ & 77 & $1.27^{\mathrm{A}}$ & 0.10 \\
Agility index & 31 & 2.85 & 32 & 2.77 & 0.24 \\
Cranial index & 31 & 0.18 & 32 & 0.18 & 0.01 \\
Relative profile & 31 & 0.23 & 32 & 0.24 & 0.02 \\
& & & & & \\
Body components & & & & & \\
Fins (\%) & 31 & 1.40 & 32 & 1.41 & 0.21 \\
Gills (\%) & 31 & $2.11^{\mathrm{a}}$ & 32 & $2.24^{\mathrm{b}}$ & 0.20 \\
Head (\%) & 31 & 12.58 & 32 & 12.02 & 1.20 \\
Filleting remnant (\%) & 31 & 9.84 & 32 & 9.80 & 1.42 \\
Hepato-somatic index (HSI, \%) & 45 & $1.01^{\mathrm{a}}$ & 47 & $0.92^{\mathrm{b}}$ & 0.18 \\
Digestive tract (\%) & 45 & 4.02 & 47 & 3.99 & 0.92 \\
Mesenteric fat (\%) & 43 & $4.08^{\mathrm{B}}$ & 47 & $5.65^{\mathrm{A}}$ & 1.36 \\
Viscero-somatic index (VSI, \%) & 45 & $8.93^{\mathrm{B}}$ & 47 & $10.55^{\mathrm{A}}$ & 1.32 \\
& & & & & \\
Dressed weight (\%) & 45 & $91.07^{\mathrm{A}}$ & 47 & $89.45^{\mathrm{B}}$ & 1.32 \\
Fillets (\%) & 45 & 56.78 & 47 & 55.55 & 4.12 \\
\hline
\end{tabular}

${ }^{1}$ Means are indicated with rsd. Different superscript letters in the same row indicate significant statistical differences (a, b: $\mathrm{P}<0.05 ; \mathrm{A}, \mathrm{B}: \mathrm{P}<0.01$ ). 
Table 6. Fillet and liver chemical composition (on wet weight basis) in rainbow trout fed diets based on fish meal (FM) or on a mixture of plant protein sources (PP) ${ }^{1}$.

\begin{tabular}{|c|c|c|c|c|c|}
\hline & $\mathrm{N}^{\circ}$ & FM & $\mathrm{N}^{\circ}$ & $\mathrm{PP}$ & rsd \\
\hline \multicolumn{6}{|l|}{ Whole fillet composition } \\
\hline Moisture (\%) & 18 & 71.96 & 21 & 72.87 & 1.61 \\
\hline Crude protein $(\%)$ & 5 & $19.93^{\mathrm{b}}$ & 6 & $20.53^{\mathrm{a}}$ & 0.40 \\
\hline Lipids $(\%)$ & 18 & $6.98^{\mathrm{A}}$ & 21 & $5.50^{\mathrm{B}}$ & 1.54 \\
\hline Ash $(\%)$ & 5 & $1.24^{\mathrm{b}}$ & 6 & $1.29^{\mathrm{a}}$ & 0.03 \\
\hline Phosphorus (\%) & 5 & 0.14 & 6 & 0.16 & 0.04 \\
\hline Cholesterol (mg / 100g) & 5 & $51.04^{\mathrm{a}}$ & 6 & $47.74^{\mathrm{b}}$ & 2.11 \\
\hline Malonaldehyde (mg / kg) & 13 & 0.058 & 15 & 0.073 & 0.026 \\
\hline \multicolumn{6}{|l|}{ Liver composition } \\
\hline Moisture (\%) & 4 & $71.31^{\mathrm{b}}$ & 6 & $74.40^{\mathrm{a}}$ & 2.13 \\
\hline Crude protein $(\%)$ & 4 & $15.30^{\mathrm{B}}$ & 6 & $16.50^{\mathrm{A}}$ & 0.54 \\
\hline Lipids $(\%)^{2}$ & 5 & 5.15 & 6 & 4.23 & 1.14 \\
\hline Ash $(\%)$ & 4 & 1.15 & 6 & 1.23 & 0.10 \\
\hline
\end{tabular}

\footnotetext{
${ }^{1}$ Means are indicated with rsd. Different superscript letters in the same row indicate significant statistical differences (a, b: $\mathrm{P}<0.05 ; \mathrm{A}, \mathrm{B}: \mathrm{P}<0.01$ ).

${ }^{2}$ For the analysis of liver lipid, samples different from those utilised for the analysis of the other chemical components were utilised.
} 


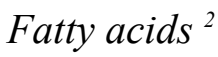

C14:0

C16:0

C16:1

C18:0

C18:1

C18:2 n-6

C18:3 n-3

C18:4 n-3

C20:1 n-9

C20:4 n-3

C20:5 n-3

C22:1 n-11

C22:5 n-3

C22:6 n-3

\section{$\Sigma$ SFA}

$\Sigma$ MUFA

$\Sigma$ PUFA n-6

$\Sigma$ PUFA n-3

n3 / n6 ratio

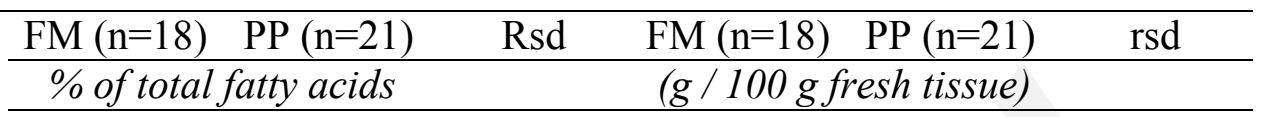

$4.75^{\mathrm{A}}$

$17.85^{\mathrm{A}}$

$4.45^{\mathrm{B}}$

0.13

$0.182^{\mathrm{a}}$

$0.146^{\mathrm{b}}$

0.042

6.25

$17.29^{\mathrm{B}}$

0.45

$0.687^{\mathrm{a}}$

$0.567^{\mathrm{b}}$

1.666

$3.30^{\mathrm{A}}$

6.35

0.55

0.242

0.208

0.063

20.12

0.21

$0.128^{\mathrm{A}}$

$0.095^{\mathrm{B}}$

0.033

21.07

1.56

0.780

0.699

0.228

$2.46^{\mathrm{B}}$

$8.59^{\mathrm{A}}$

0.28

$0.094^{\mathrm{B}}$

$0.282^{\mathrm{A}}$

0.059

$0.87^{\mathrm{B}}$

$1.03^{\mathrm{A}}$

0.05

0.033

0.034

0.009

1.64

1.65

$7.63^{\mathrm{A}}$

$5.79^{\mathrm{B}}$

0.10

0.063

0.054

0.016

$1.44^{\mathrm{A}}$

$0.86^{\mathrm{B}}$

0.21

$0.294^{\mathrm{A}}$

$0.191^{\mathrm{B}}$

0.065

6.05

5.59

0.09

$0.055^{\mathrm{A}}$

$0.028^{\mathrm{B}}$

0.011

5.69

4.94

1.06

$0.235^{\mathrm{a}}$

$0.182^{\mathrm{b}}$

0.065

$1.64^{\mathrm{a}}$

$1.46^{\mathrm{b}}$

1.86

$0.236^{\mathrm{a}}$

$0.165^{\mathrm{b}}$

0.082

0.27

$0.064^{\mathrm{A}}$

$0.048^{\mathrm{B}}$

0.018

2.63

$0.576^{\mathrm{a}}$

$0.479^{\mathrm{b}}$

0.145

\begin{tabular}{cccccc}
$26.58^{\mathrm{A}}$ & $25.25^{\mathrm{B}}$ & 0.60 & $1.023^{\mathrm{a}}$ & $0.829^{\mathrm{b}}$ & 0.246 \\
$41.46^{\mathrm{A}}$ & $38.55^{\mathrm{B}}$ & 1.40 & $1.601^{\mathrm{a}}$ & $1.269^{\mathrm{b}}$ & 0.400 \\
$3.46^{\mathrm{B}}$ & $9.92^{\mathrm{A}}$ & 0.30 & $0.132^{\mathrm{B}}$ & $0.325^{\mathrm{A}}$ & 0.069 \\
$27.87^{\mathrm{A}}$ & $25.43^{\mathrm{B}}$ & 1.99 & $1.065^{\mathrm{A}}$ & $0.828^{\mathrm{B}}$ & 0.232 \\
& & & $15.739^{\mathrm{A}}$ & $4.052^{\mathrm{B}}$ & 4.369 \\
\hline
\end{tabular}

${ }^{1}$ Means are indicated with rsd. Different superscript letters in the same row indicate significant statistical differences (a, b: $\mathrm{P}<0.05 ; \mathrm{A}, \mathrm{B}: \mathrm{P}<0.01)$.

${ }^{2}$ The fatty acids C12:0, C15:0, C16:2 n-4, C16:3 n-3, C16:4 n-1, C17:0, C18:2 n-4, C18:3 n-4, C18:3 n-6, C20:0, C20:1 n-7, C20:2 n-6, 20:3 n-3, C20:3 n-6, C20:4 n-6, C22:1 n-9, C21:5 n-3, C22:4 n-6, C22:5 n-6, in percentage less than $1 \%$, were considered in the composite fractions but not reported in the table for brevity. 
Table 8. Fatty acid composition of livers from trout fed diets based on fish meal (FM) or on a mixture of plant protein sources $(\mathrm{PP})^{1}$.

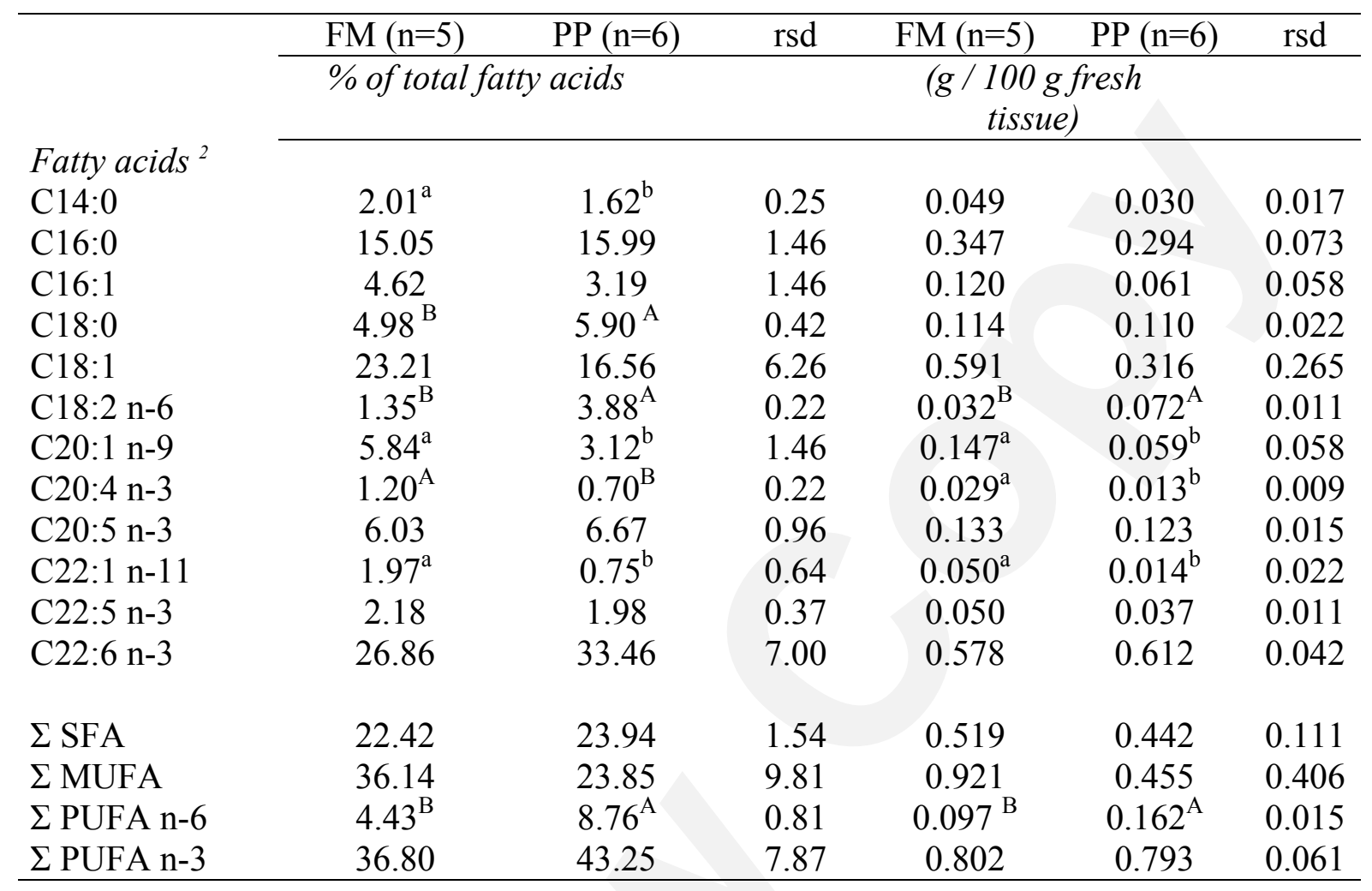

${ }^{1}$ Means are indicated with rsd. Different superscript letters in the same row indicate significant statistical differences (a, b: $\mathrm{P}<0.05 ; \mathrm{A}, \mathrm{B}: \mathrm{P}<0.01$ ).

${ }^{2}$ The fatty acids C12:0, C15:0, C16:2 n-4, C16:3 n-3, C16:4 n-1, C17:0, C18:2 n-4, C18:3 n-3, C18:4 n-4, C18:3 n-4, C18:3 n-6, C20:0, C20:1 n-7, C20:2 n-6, 20:3 n-3, C20:3 n-6, C20:4 n-6, C22:1 n-9, C21:5 n-3, C22:4 n-6, C22:5 n-6, in percentage less than $1 \%$, were considered in the composite fractions but not reported in the table for brevity. 
Table 9. Parameters of fillet colour in rainbow trout fed diets based on fish meal (FM) or on a mixture of plant protein sources (PP).

\begin{tabular}{|c|c|c|c|}
\hline & $\mathrm{FM}(\mathrm{n}=36)$ & $P P(n=39)$ & rsd \\
\hline \multicolumn{4}{|l|}{ Parameters } \\
\hline \multicolumn{4}{|l|}{ Dorsal site } \\
\hline Lightness & 36.82 & 36.50 & 2.16 \\
\hline $\mathrm{a}$ & $11.29^{\mathrm{a}}$ & $10.45^{\mathrm{b}}$ & 1.69 \\
\hline $\mathrm{b}$ & $12.91^{\mathrm{B}}$ & $15.02^{\mathrm{A}}$ & 3.05 \\
\hline Chroma & 17.18 & 18.35 & 3.23 \\
\hline $\mathrm{Hue}^{\circ}$ & $48.59^{\mathrm{B}}$ & $54.89^{\mathrm{A}}$ & 4.34 \\
\hline \multicolumn{4}{|l|}{ Ventral site } \\
\hline Lightness & $35.62^{\mathrm{a}}$ & $34.54^{\mathrm{b}}$ & 1.95 \\
\hline $\mathrm{a}$ & $9.25^{\mathrm{A}}$ & $8.37^{\mathrm{B}}$ & 1.34 \\
\hline $\mathrm{b}$ & $10.53^{\mathrm{B}}$ & $12.34^{\mathrm{A}}$ & 2.32 \\
\hline Chroma & 14.09 & 14.95 & 2.37 \\
\hline $\mathrm{Hue}^{\circ}$ & $48.20^{\mathrm{B}}$ & $55.75^{\mathrm{A}}$ & 4.78 \\
\hline \multicolumn{4}{|l|}{ Caudal site } \\
\hline Lightness & 34.86 & 34.76 & 2.03 \\
\hline $\mathrm{a}$ & $11.67^{\mathrm{A}}$ & $10.42^{\mathrm{B}}$ & 1.55 \\
\hline $\mathrm{b}$ & $12.35^{\mathrm{b}}$ & $13.59^{\mathrm{a}}$ & 2.25 \\
\hline Chroma & 17.07 & 17.20 & 2.44 \\
\hline $\mathrm{Hue}^{\circ}$ & $46.19^{\mathrm{B}}$ & $52.25^{\mathrm{A}}$ & 4.20 \\
\hline
\end{tabular}

${ }^{1}$ Means are indicated with rsd. Different superscript letters in the same row indicate significant statistical differences (a, b: $\mathrm{P}<0.05 ; \mathrm{A}, \mathrm{B}: \mathrm{P}<0.01)$. 
Fig. 1. Body weight changes in rainbow trout fed diet FM or PP

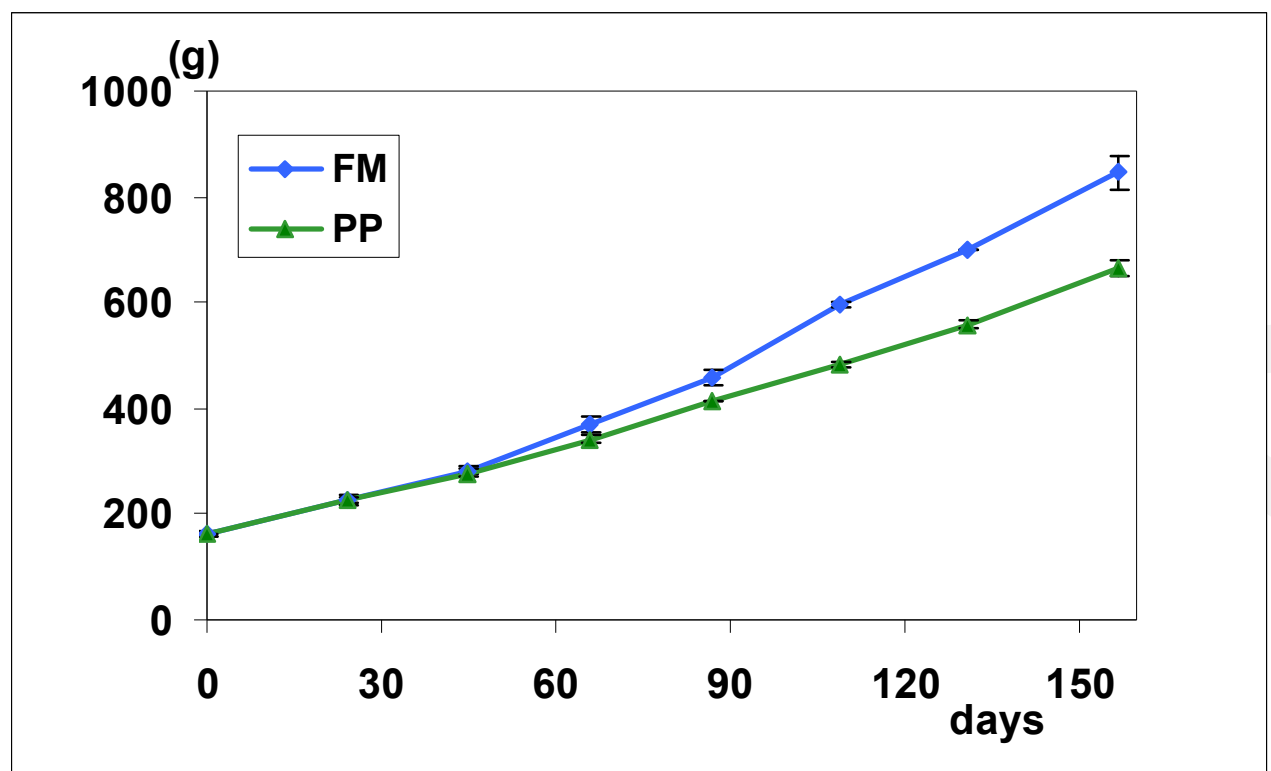


Fig. 2. Sensory evaluation of cooked fillets at 5 days after death, results of the descriptive test $\left(2=2^{\text {st }}\right.$ replication, $2^{\text {nd }}=2$ replication $)$.

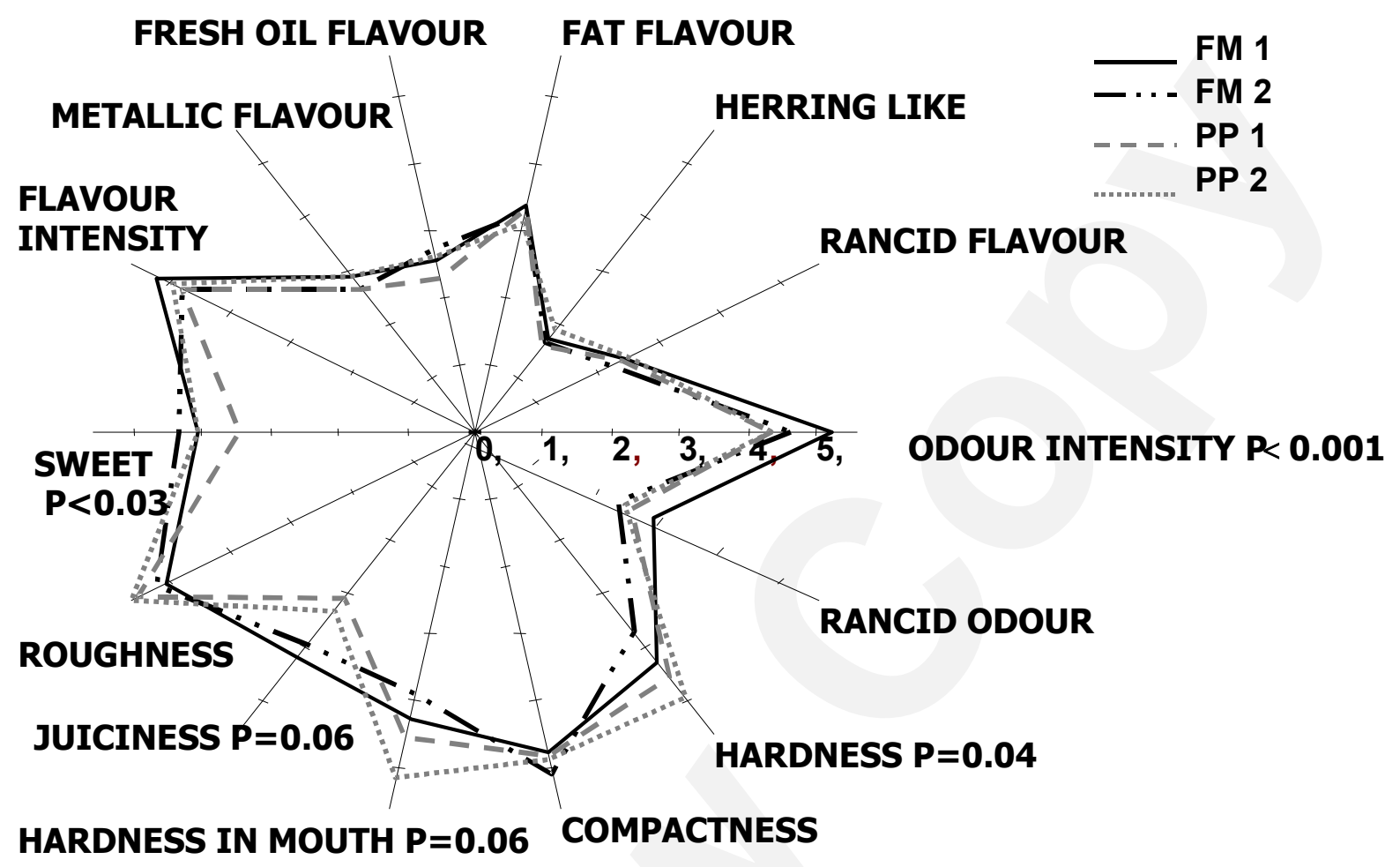

